\title{
PHILOSOPHY AS A SYSTEM OF CONDITIONALS*
}

\begin{abstract}
Philosophical statements are often suppositions. Gottfried Wilhelm Leibniz proposes in Nouveaux Essais sur l'entendement humain, 1704, a method of the construction of assertive conditionals occurring between any philosophical suppositions. If we can infer a philosophical statement from any suppositions then the implication between these suppositions and the obtained statement is assertive. In the article, some examples of the application of Leibniz's method are considered.
\end{abstract}

Keywords: Leibniz; theodicy; supposition; conditionals

The purpose of the sciences about reality is to make assertive, certain statements. Assumptions, opinions are treated as a concession to methodological deficiencies. There are also suppositions which allow for what is logically possible, not contradictory. Philosophy seems to be located in this situation of the weakest bases. Here are some philosophers who accept, for example, suppositions that there is an absolute, immaterial soul, immortality, sense of life, etc., while others, on the contrary, recognise the negation of such suppositions, which also only has the power of suppositions ${ }^{1}$. And the philosopher's subjective assertions are irrelevant.

Leibniz proposes to philosophy to get out of this enchanted circle of suppositions: "It must be added that even principles whose certainty is not absolute can apply if you build on them only by com-

* This article was originally published in Polish as: E. Nieznański, Filozofia jako system okresów warunkowych, Studia Philosophiae Christiane 45(2009)2, 7-14. The translation of the article into English was financed by the Ministry of Science and Higher Education of the Republic of Poland as part of the activities promoting science - Decision No. 676/P-DUN/2019 of 2 April 2019. Translation made by GROY Translations.

1 For the sake of comparison, let us quote Henryk Mehlberg's thesis, "The fact that there are unproven assumptions in empirical science seems unquestionable". H. Mehlberg, O niesprawdzalnych założeniach nauki, in: Logiczna teoria nauki, ed. T. Pawłowski, PWN, Warszawa 1966, 359. 
mand. Although in this case all the conclusions are only conditional and depend on a presumption of the truth of these principles, at least the dependencies and conditional sentences themselves remain valid. So it is very desirable that we have many works written using this method" 2 . Therefore, if from the set of suppositions: $p_{1}, p_{2}, \ldots, p_{n}$, a $q$ sentence can be deducted according to the rules of formal logic, then the implication $\left(p_{1} \wedge p_{2} \wedge \ldots \wedge p_{n}\right) \rightarrow q$ is certain and sufficiently justified. Let us demonstrate this practice on an example of theodicy. Let us assume that we already have the concept of inherence ratio " $\varepsilon$ "("is") as a reflexive, transitive and antisymmetric relation, ${ }^{3}$ according to the semantic postulates:

P1. $\forall \mathrm{x} \mathrm{x \& x}$

P2. $\forall \mathrm{x} \forall \mathrm{y} \forall \mathrm{z}(\mathrm{x} \varepsilon \mathrm{y} \wedge \mathrm{y} \varepsilon \mathrm{z} \rightarrow \mathrm{x} \varepsilon \mathrm{z})$,

Df.: $\mathrm{x}=\mathrm{y} \leftrightarrow \mathrm{x} \varepsilon \mathrm{y} \wedge \mathrm{y} \varepsilon \mathrm{x}$,

the concept of the counter-return of a part to whole $(C)$ :

P3. $\forall \mathrm{x} \sim \mathrm{x} C \mathrm{x}$,

as well as the original concept of raison d'etre $(R)$ with the intention of meaning that identities and parts are raison d'etre:

P4. $\forall z \forall x[(z=x \vee z C x) \rightarrow z R x]$.

Then we can define the concept of sufficient raison d'etre $(D)$, the concept of the absolute $(A)$ and the simple being $(P)$ :

Df.D: $x D y \leftrightarrow x R y \wedge \forall z(z R x \rightarrow z=x)$

( $x$ is sufficient ration $y-a \leftrightarrow x$ is ration $y-a$ and each ration $x-a$ is identical to $x$-em. Sufficient raison d'etre is its minimum ration)

Df.A: $x \varepsilon A \leftrightarrow \forall z(z R x \leftrightarrow z=x)$

(Absoluteness is the same as any raison d'etre of existence; it is right in itself and has no right ab alio)

Df.P: $x \varepsilon P \leftrightarrow \sim \exists z z C x$

(Simple being is being without parts)

2 G. W. Leibniz, Nowe rozważania dotyczące rozumu ludzkiego, transl. I. Dąmbska, Antyk, Kęty 2001, 393-394.

3 This sense of the relation "... is ..." is equivalent to the relation "each ... is ...", it is different from the meaning adopted in Leśniewski Ontology. See: E. Nieznański, Logika. Podstawy - język - uzasadnianie, Wydawnictwo C. H. Beck, Warszawa 2000, 153-164. 
We will prove the three conditionals relevant to the theodicy:

Tw.1: $\forall \mathrm{y} \exists \mathrm{x} x D \mathrm{y} \rightarrow \exists \mathrm{x} \varepsilon \mathrm{A}$

(If the principle of sufficient raison d'etre applies, there is an absolute)

\section{Proof}

$\forall y \exists x x D y$, thus $\exists x x D a$, thus bDa, Df.D, thus $\forall z(z R b \rightarrow z=b)$, P4, thus $\forall z(z R b \leftrightarrow z=b)$, Df.A, thus beA, thus $\exists x x \varepsilon A$.

Tw.2: $\forall \mathrm{x}(\mathrm{x} \varepsilon \mathrm{A} \rightarrow \mathrm{x} \varepsilon \mathrm{P})$

(absolute is simple being)

Proof by contradiction

$\mathrm{P} 3, \mathrm{P} 4$, thus $\forall \mathrm{x} \sim \mathrm{xCx}, \forall \mathrm{z} \forall \mathrm{x}(\mathrm{zCx} \rightarrow \mathrm{zRx}), \mathrm{x} \varepsilon \mathrm{A}, \sim \mathrm{x} \varepsilon \mathrm{P}$ (assumption of proof by contradiction), Df.P, thus $\exists \mathrm{z} z \mathrm{Cx}$, thus $\mathrm{aCx}$, thus $\mathrm{aRx}$, Df.A, więc $\mathrm{a}=\mathrm{x}$, thus $\mathrm{xCx}, \sim \mathrm{xCx}$, thus contradiction.

Tw.3: $\forall \mathrm{x}(\mathrm{x} \varepsilon \mathrm{M} \rightarrow \sim \mathrm{x} \varepsilon \mathrm{P}) \wedge \mathrm{x} \varepsilon \mathrm{A} \rightarrow \sim \mathrm{x} \varepsilon \mathrm{M}$, where "M" is a "material being"

(If no material being is simple, the absolute is immaterial)

\section{Proof}

P3, P4, thus $\forall \mathrm{x} \sim \mathrm{xCx}, \forall \mathrm{z} \forall \mathrm{x}(\mathrm{zCx} \rightarrow \mathrm{zRx}), \forall \mathrm{x}(\mathrm{x} \varepsilon \mathrm{M} \rightarrow \sim \mathrm{x} \varepsilon \mathrm{P})$, $\mathrm{x} \varepsilon \mathrm{A}, \mathrm{Tw} .2$, thus $\mathrm{x} \varepsilon \mathrm{P}$, thus $\sim \mathrm{x} \varepsilon \mathrm{M}$.

Sometimes it is useful to translate the implication into an alternative, as defined:

Df. $\vee(p \vee q) \leftrightarrow(\sim p \rightarrow q)$

A logical tautology is, for example, a thesis:

Tw.4: $(\mathrm{p} \rightarrow \sim \mathrm{q}) \rightarrow\{(\mathrm{p} \rightarrow \mathrm{q}) \rightarrow[(\sim \mathrm{p} \rightarrow \sim \mathrm{q}) \rightarrow \sim(\sim \mathrm{p} \rightarrow \mathrm{q})]\}$

Proof by contradiction

$(\mathrm{p} \rightarrow \sim \mathrm{q}),(\mathrm{p} \rightarrow \mathrm{q}),(\sim \mathrm{p} \rightarrow \sim \mathrm{q}), \sim \mathrm{p} \rightarrow \mathrm{q}$ (assumption of proof by contradiction), thus $\mathrm{q} \rightarrow \sim \mathrm{p}$, thus $\mathrm{p} \rightarrow \sim \mathrm{p}$, thus $\sim \mathrm{p}$, thus $\mathrm{q}, \sim \mathrm{q}$, thus contradiction. Tw.4 is inferentially equivalent to the alternative Tw.5:

Tw.5: $(\mathrm{p} \wedge \mathrm{q}) \vee(\mathrm{p} \wedge \sim \mathrm{q}) \vee(\sim \mathrm{p} \wedge \mathrm{q}) \vee(\sim \mathrm{p} \wedge \sim \mathrm{q})$

\section{Proof}

Tw.5 only if $\sim \sim(\mathrm{p} \wedge \mathrm{q}) \vee \sim \sim(\mathrm{p} \wedge \sim \mathrm{q}) \vee \sim \sim(\sim \mathrm{p} \wedge \mathrm{q}) \vee \sim \sim(\sim \mathrm{p} \wedge \sim \mathrm{q})$ only if $\sim(\mathrm{p} \rightarrow \sim \mathrm{q}) \vee \sim(\mathrm{p} \rightarrow \mathrm{q}) \vee \sim(\sim \mathrm{p} \rightarrow \sim \mathrm{q}) \vee \sim(\sim \mathrm{p} \rightarrow \mathrm{q})$ only if Tw.4. 
An alternative is also a tautology:

Tw.6: $(\mathrm{p} \wedge \mathrm{q} \wedge \mathrm{r}) \vee(\mathrm{p} \wedge \mathrm{q} \wedge \sim \mathrm{r}) \vee(\mathrm{p} \wedge \sim \mathrm{q} \wedge \mathrm{r}) \vee(\mathrm{p} \wedge \sim \mathrm{q} \wedge \sim \mathrm{r}) \vee(\sim \mathrm{p} \wedge \mathrm{q} \wedge \mathrm{r})$ $\vee(\sim \mathrm{p} \wedge \mathrm{q} \wedge \sim \mathrm{r}) \vee(\sim \mathrm{p} \wedge \sim \mathrm{q} \wedge \mathrm{r}) \vee(\sim \mathrm{p} \wedge \sim \mathrm{q} \wedge \sim \mathrm{r})$

Proof by contradiction

$\sim$ Tw.6 (assumption of proof by contradiction), thus $\sim(\mathrm{p} \wedge \mathrm{q} \wedge \mathrm{r})$, $\sim(\mathrm{p} \wedge \mathrm{q} \wedge \sim \mathrm{r}), \quad \sim(\mathrm{p} \wedge \sim \mathrm{q} \wedge \mathrm{r}), \sim(\mathrm{p} \wedge \sim \mathrm{q} \wedge \sim \mathrm{r}), \sim(\sim \mathrm{p} \wedge \mathrm{q} \wedge \mathrm{r}), \sim(\sim \mathrm{p} \wedge \mathrm{q} \wedge \sim \mathrm{r})$, $\sim(\sim \mathrm{p} \wedge \sim \mathrm{q} \wedge \mathrm{r}), \sim(\sim \mathrm{p} \wedge \sim \mathrm{q} \wedge \sim \mathrm{r})$, thus $(\mathrm{p} \wedge \mathrm{q} \rightarrow \sim \mathrm{r}),(\mathrm{p} \wedge \mathrm{q} \rightarrow \mathrm{r}),(\mathrm{p} \wedge \sim \mathrm{q} \rightarrow \sim \mathrm{r})$, $(\mathrm{p} \wedge \sim \mathrm{q} \rightarrow \mathrm{r}),(\sim \mathrm{p} \wedge \mathrm{q} \rightarrow \sim \mathrm{r}),(\sim \mathrm{p} \wedge \mathrm{q} \rightarrow \mathrm{r}),(\sim \mathrm{p} \wedge \sim \mathrm{q} \rightarrow \sim \mathrm{r}),(\sim \mathrm{p} \wedge \sim \mathrm{q} \rightarrow \mathrm{r})$, thus $\sim(\mathrm{p} \wedge \mathrm{q}), \sim(\mathrm{p} \wedge \sim \mathrm{q}), \sim(\sim \mathrm{p} \wedge \mathrm{q}), \sim(\sim \mathrm{p} \wedge \sim \mathrm{q})$, thus $\mathrm{p} \rightarrow \sim \mathrm{q}, \mathrm{p} \rightarrow \mathrm{q}, \sim \mathrm{p} \rightarrow \sim \mathrm{q}$, $\sim \mathrm{p} \rightarrow \mathrm{q}$, thus $\sim \mathrm{q} \rightarrow \mathrm{p}$, thus $\sim \mathrm{p} \rightarrow \mathrm{p}$, thus $\mathrm{p}$, thus $\mathrm{q}, \sim \mathrm{q}$, thus contradiction.

The statements made by Tw.5 and Tw.6 will prove useful for our further deliberations. Let us first note that the philosopher does not seek empirical laws or types. He devotes all his attention to the nature of things and matters of interest to him. What is nature? $\mathrm{Na}-$ ture is "the essence of being (an individual substance, an affliction) as the basis of qualities: what a given thing is in itself" 4 . In the nature of things, we distinguish its constitutive components (essential aspects, principles). Let the symbol $\alpha(\mathrm{x})$ denote an important aspect of nature $\mathrm{x}-\mathrm{a}$. Then " $\mathrm{a} \varepsilon \alpha(\mathrm{x})$ " is read: "a is an essential aspect of nature $\mathrm{x}-\mathrm{a}$ (its principle)". The aspects remain in opposition to one another $(\mathrm{O})$ : either complementary $(\mathrm{OK})$ or disjunctive $(\mathrm{OD})$. We define these oppositions:

Df.OK: OKab $\leftrightarrow \forall \mathrm{x}(\mathrm{x} \varepsilon \mathrm{a} \leftrightarrow \sim \mathrm{x} \varepsilon \mathrm{b})$

(a remains in complementary opposition to $\mathrm{b}$, when $\mathrm{a}$ and $\mathrm{b}$ are contradictory)

Df.OD: Odab $\leftrightarrow \forall x(x \varepsilon a \rightarrow \sim x \varepsilon b)$

(a remains in disjunctive opposition to $\mathrm{b}$, when $\mathrm{a}$ and $\mathrm{b}$ are opposite)

Df.O: $\mathrm{Oab} \leftrightarrow(\mathrm{OKab} \vee \mathrm{ODab})$

(a remains in opposition to $\mathrm{b}$, when a remains in disjunctive or complementary opposition to $\mathrm{b}$ )

4 A. Posiad, Słownik terminów i pojęć filozoficznych, PAX, Warszawa 2000, 546. 
Instead of the opposition, we will also talk about complements. The opposing component of the opposition is called the complement. If e.g. the being and existence are components of the opposition, then the being is called the complement of existence, and vice versa: existence - the complement of the being. The rules are put together in opposition pairs as suggested by Izydora Dąmbska: “... a certain duality is imposed on us both in the construction of the reality we present ourselves and in the forms of cognition, and that at the same time there exists a certain ambition in the conscious subject, which forces them to reduce and remove this duality in various ways, substituting it with some unity" . The Oab opposition is a single opposition. Multiple oppositions $\left(\mathrm{O}^{\mathrm{n}}\right)$ are defined by single oppositions:

Df. $\mathrm{O}^{\mathrm{n}}: \mathrm{O}^{\mathrm{n}}\left(\mathrm{a}, \mathrm{a}_{1}, \mathrm{a}_{2}, \ldots, \mathrm{a}_{\mathrm{n}}\right) \leftrightarrow \forall \mathrm{i}\left(\mathrm{i} \leq \mathrm{n} \rightarrow \mathrm{Oaa}{ }_{\mathrm{i}}\right)$

(a remains in $n$-fold opposition to the sequence $a_{1}, a_{2}, \ldots, a_{n}$, if a remains in a single opposition to each term of that sequence)

For example, In relation to an assertion, multiple (twofold) oppositions (complements) are assumption and supposition (these are disjunctive complements). The relation of a single opposition is non-reflexive (Tw.7) and symmetrical (Tw.8) in a set of principles:

Tw.7: $\forall \mathrm{a} \forall \mathrm{b}(\mathrm{Oab} \rightarrow \sim \mathrm{a} \varepsilon \mathrm{b})$

Proof

Oab, thus $\forall \mathrm{x}(\mathrm{x} \varepsilon \mathrm{a} \rightarrow \sim \mathrm{x} \varepsilon \mathrm{b})$, a $\mathrm{a} a$, thus $\sim \mathrm{a} \varepsilon \mathrm{b}$.

Tw.8: $\forall \mathrm{a} \forall \mathrm{b}(\mathrm{Oab} \rightarrow \mathrm{Oba})$

Proof

Oab, Df.O, Df.OK, Df.OD, thus $\forall x(x \varepsilon a \leftrightarrow \sim x \varepsilon b) \vee \forall x(x \varepsilon a \rightarrow \sim x \varepsilon b)$, thus

$\forall \mathrm{x}(\mathrm{x} \varepsilon \mathrm{b} \leftrightarrow \sim \mathrm{x} \varepsilon \mathrm{a}) \vee \forall \mathrm{x}(\mathrm{x} \varepsilon \mathrm{b} \rightarrow \sim \mathrm{x} \varepsilon \mathrm{a})$, thus Oba.

5 I. Dąmbska, o dwoistości w aspekcie bytu i poznania i o tendencji do przezwyciężania tej dwoistości jako podstawie kierunków i stanowisk filozoficznych, in: Jak filozofować? Studia z metodologii filozofii, eds. J. Kmita, J. Topolski, PWN, Warszawa 1989, 13-21. 
The relation between the principles and the opposition is linked to the semantic postulate:

P5. $\forall \mathrm{a} \forall \mathrm{b} \forall \mathrm{x}[\mathrm{a} \varepsilon \alpha(\mathrm{x}) \wedge \mathrm{Oab} \rightarrow \mathrm{b} \varepsilon \alpha(\mathrm{x})]$

(Complementation of a principle is the principle)

Two principles $\mathrm{a}$ and $\mathrm{b}$ standing in a single opposition to each other Oab a predicate $\mathrm{F}$ - according to Tw. 5 - can be decided in exactly four ways:

$$
\begin{aligned}
& \mathrm{F}(\mathrm{a}) \wedge \mathrm{F}(\mathrm{b}) \vee \\
& \mathrm{F}(\mathrm{a}) \wedge \sim \mathrm{F}(\mathrm{b}) \vee \\
& \sim \mathrm{F}(\mathrm{a}) \wedge \mathrm{F}(\mathrm{b}) \vee \\
& \sim \mathrm{F}(\mathrm{a}) \wedge \sim \mathrm{F}(\mathrm{b}) .
\end{aligned}
$$

The three principles $\mathrm{a}, \mathrm{b}$ and $\mathrm{c}$ standing in double opposition to each other $\mathrm{O}^{2}(\mathrm{a}, \mathrm{b}, \mathrm{c})$ a predicate $\mathrm{F}$ - according to Tw. 6 - can be decided in exactly eight ways:

$$
\begin{aligned}
& \mathrm{F}(\mathrm{a}) \wedge \mathrm{F}(\mathrm{b}) \wedge \mathrm{F}(\mathrm{c}) \vee \\
& \mathrm{F}(\mathrm{a}) \wedge \mathrm{F}(\mathrm{b}) \wedge \sim \mathrm{F}(\mathrm{c}) \vee \\
& \mathrm{F}(\mathrm{a}) \wedge \sim \mathrm{F}(\mathrm{b}) \wedge \mathrm{F}(\mathrm{c}) \vee \\
& \mathrm{F}(\mathrm{a}) \wedge \sim \mathrm{F}(\mathrm{b}) \wedge \sim \mathrm{F}(\mathrm{c}) \vee \\
& \sim \mathrm{F}(\mathrm{a}) \wedge \mathrm{F}(\mathrm{b}) \wedge \mathrm{F}(\mathrm{c}) \vee \\
& \sim \mathrm{F}(\mathrm{a}) \wedge \mathrm{F}(\mathrm{b}) \wedge \sim \mathrm{F}(\mathrm{c}) \vee \\
& \sim \mathrm{F}(\mathrm{a}) \wedge \sim \mathrm{F}(\mathrm{b}) \wedge \mathrm{F}(\mathrm{c}) \vee \\
& \sim \mathrm{F}(\mathrm{a}) \wedge \sim \mathrm{F}(\mathrm{b}) \wedge \sim \mathrm{F}(\mathrm{c}) .
\end{aligned}
$$

Most often, philosophical standpoints are based on a single opposition of principles, less often - on double and quite exceptionally on oppositions with more components. The relation between the two principles and the standpoints advocating the $\mathrm{F}$ predicate about them is illustrated in the table: 


\begin{tabular}{|c|c|c|}
\hline Standpoints/rules & I & II \\
\hline 1. & + & + \\
\hline 2. & + & - \\
\hline 3. & - & + \\
\hline 4. & - & - \\
\hline
\end{tabular}

Where “+” means $F(\ldots)$, a “-” - $F(\ldots)$.

Examples:

(1) By the nature of being: I spirit, II matter; 1. dualism, 2. spiritualism, 3. materialism, 4. neutral monism.

(2) By the complementarity of being: I God, II world; 1. dualism, 2. pantheism, 3. atheism, 4. nihilism.

(3) By the entity of being: I entity in se, II entity ab alio; 1. aggregate, 2 . substance, 3 . condition, 4 . non-being.

(4) By raisons d'être: I ration in se, II ration ab alio; 1.unnecessary being, 2. necessary being, 3. unnecessary non-being, 4. necessary non-being.

(5) By types of cognition: I rational cognition, II sensual cognition; 1. moderate empiricism, 2. extreme apriorism, 3. extreme empiricism, 4. irrationalism.

(6) Due to the being of idea: I sensual empirical beings, II ideal objects; 1. moderate realism, 2. nominalism, 3. platonism, 4. non-essentialism.

(7) By the ultimate motivation of human life: I rush to joy, II strive for perfection; 1. eudemonism, 2. hedonism, 3. perfectionism, 4. cynicism.

The next table illustrates the situation where the alternative of eight standpoints includes three principles:

\begin{tabular}{|c|c|c|c|}
\hline Standpoints/rules & I & II & III \\
\hline 1. & + & + & + \\
\hline 2. & + & + & - \\
\hline 3. & + & - & + \\
\hline 4. & + & - & - \\
\hline
\end{tabular}




\begin{tabular}{|c|c|c|c|}
\hline 5. & - & + & + \\
\hline 6. & - & + & - \\
\hline 7. & - & - & + \\
\hline 8. & - & - & - \\
\hline
\end{tabular}

Examples:

(1) By the nature of the judgments that exist in science: I assertive, II hypothetical, III suppositional following standpoints are possible: 1. radical criticism, 2. moderate criticism, 3. moderate dogmatism, 4. radical dogmatism, 5. moderate hypothetism, 6. extreme hypothetism, 7. moderate scepticism, 8. extreme scepticism;

(2) By the actual existence of principles: I things, II phenomena, III ideas we get standpoints: 1. phenomenology, 2. realism, 3. Platonic reism, 4. radical reism, 5. Platonism, 6. phenomenism, 7. Platonic fictionism, 8. radical fictionism;

(3) By the purposes of people's acts: I for themselves, II for others, III for nobody (for what is not a person). Standpoints: 1. moderate naturalism, 2. extreme naturalism, 3. moderate egoism, 4. extreme egoism, 5. moderate altruism, 6. extreme altruism, 7. moderate indifferentism, 8. extreme indifferentism.

In a philosophical system of legitimate conditionals and alternatives, as outlined here, a philosopher can define the spectrum and boundaries of solutions in any matter. The choice of a single standpoint is more often a matter of motives than rights.

\section{BIBLIOGRAPHY:}

Dąmbska I., O dwoistości w aspekcie bytu i poznania i o tendencji do przezwyciężania tej dwoistości jako podstawie kierunków i stanowisk fllozoficznych, in: Jak filozofować? Studia z metodologii filozofi, eds. J. Kmita, J. Topolski, PWN, Warszawa 1989, 13-21.

Leibniz G. W., Nowe rozważania dotyczace rozumu ludzkiego, transl. I. Dąmbska, Antyk, Kęty 2001.

Mehlberg H., O niesprawdzalnych zatożeniach nauki, in: Logiczna teoria nauki, ed. T. Pawłowski, PWN, Warszawa 1966, 241-359. 
Nieznański E., Logika. Podstawy-jezzyk-uzasadnianie, Wydawnictwo C. H. Beck, Warszawa 2000.

Posiad A., Stownik terminów i pojęć fllozoficznych, PAX, Warszawa 2000.

Edward Nieznański

DOI: $10.21697 /$ spch.2020.56.S1.05 